\title{
Buffalo Boy testifies: decolonising visual testimony in a colonial-settler society
}

\author{
LYNNE BELL
}

\section{Introduction}

In this article, I will examine two visual projects by the artist Adrian Stimson: an installation entitled Old Sun (2008) and a performance-art event entitled Buffalo Boy's Confessional: Indulgence (2007). These works reveal and give shape to a particular chapter in Canada's history of colonialism: the long and unfinished story of the residential school system. This colonial system of schooling was founded and operated through a state-church partnership for more than a century until the final school closures in $1986 .{ }^{1}$ In its attempts to 'kill the Indian in the child', the residential school subjected Indigenous children to a Euro-Canadian curriculum designed to obliterate generations of Aboriginal culture. This type of assimilative educational practice is clearly identified in the United Nations Declaration on the Rights of Indigenous Peoples (2007) as cultural genocide. ${ }^{2}$ In my focus on Stimson's two projects of visual testimony, I consider the questions: how can contemporary installation and performance art illuminate and interrogate the multifaceted ways in which settler colonialism inflicts trauma - in the past and present? What is the affective and critical force of Stimson's visual acts of witnessing and how do they engage the spectator? What decolonising testimonies and pedagogies can his projects perform in the 'now' of the art event (and beyond)?

On 11 June 2008, the Prime Minister of Canada made a long-awaited public apology to the country's Indigenous peoples for the pain, suffering and hurt inflicted on them by the residential system of schooling. Responding to the apology from the floor of the House of Commons, Phil Fontaine, National Chief of the Assembly of First Nations, opened his remarks by remembering and honouring 'all of the generations who had never heard an apology, never

1 Milloy, John S. 2006, A National Crime: The Canadian Government and the Residential School System 1879 to 1986, The University of Manitoba Press, Winnipeg, p. xvii.

2 Henderson, James (Sa'ke'j) Youngblood 2006, First Nations Jurisprudence and Aboriginal Rights: Defining the just society, Native Law Centre, University of Saskatchewan, Saskatoon, Saskatchewan, pp. 149-59. 
received compensation, yet courageously fought assimilation so that Aboriginal people could witness this day'. ${ }^{3}$ Noting that the Government of Canada had taken full responsibility for the racist policy that created the residential school, Fontaine stated:

For the generations that will follow us, we bear witness today in this House, that our survival as First Nations peoples in this land is affirmed forever...Never again will this House consider us the 'Indian problem' just for being who we are. Never again will the awesome power of government attempt to destroy us, to obliterate our cultures and languages from this land - the land we have occupied since time immemorial. Never again will there be an attempt 'to kill the Indian in the child'...Brave survivors, through the telling of our painful stories, have stripped white supremacy of its authority and legitimacy. ${ }^{4}$

In concluding, Fontaine notes that Indigenous people are - and always have been - an indispensable part of the Canadian identity. He then issued a challenge to all peoples living in Canada: 'We must not falter in our duty now: emboldened by this spectacle of history, it is possible to end our racial nightmare together. ${ }^{\prime 5}$

Two years before this day of apology in the House of Commons, a court-ordered Indian Residential Schools Settlement Agreement (IRSSA) was reached between Survivors, churches and the Canadian Government. This agreement has five major components: a Common Experience Payment (CEP) providing a lumpsum payment to former residential school students; an Independent Assessment Process (IAP) providing compensation for students who suffered serious sexual, physical or psychological abuse; funding to support the creation of memorials and community healing initiatives; and a five-year Truth and Reconciliation Commission (TRC). ${ }^{6}$

As the cornerstone of the Settlement Agreement, the independent body of the TRC will focus on listening to the oral testimony of Survivors and former employees of the residential school system. Survivor testimony-the 'truths' of the previously silenced speaking subject - is central to the work of the TRC. During its five-year mandate, the TRC will travel the country, generating a public archive of testimony that will provide 'a comprehensive historical record on the policies and operations of the schools' and describe 'what happened to

\footnotetext{
3 Fontaine, Phil 2008, Apology response, 11 June 2008, House of Commons, Ottawa, <http://www.afn.ca/ cmslib/general/08-06-11\%20National\%20Chief\%20Phil\%20Fontaine.doc>

4 Ibid.

5 Ibid

6 On 10 June 2009, the TRC appointed the Honourable Justice Murray Sinclair as chairman and Marie Wilson and Chief Wilton Littlechild as commissioners (http://www.trc-cvr.ca/index_e.html).
} 
First Nations, Métis and Inuit children who attended those schools' ${ }^{7}$ In his comments on the launch of the Canadian TRC, Georges Erasmus, President of the Aboriginal Healing Foundation, noted that ' $[\mathrm{t}]$ he Truth and Reconciliation Commission, in bearing witness to what has gone before, will help to create collective memory and shared hope that will benefit Aboriginal and nonAboriginal peoples in Canada long into the future' ${ }^{8}$

In recent years, as Rice and Snyder point out, many governments have turned to truth and reconciliation commissions in order 'to heal broken relationships within society'. ${ }^{9}$ Based on principles of restorative or transitional justice with 'broad political goals of reconciliation', these commissions 'highlight the importance of healing individuals and society after the trauma of mass violence, such as the violence perpetrated in Indian Residential Schools.$^{10}$ In discussing the international genre of the truth commission, Deborah Posel points to a central tension or dilemma in the workings of restorative or transitional justice: 'Truth commissions have been fashioned to grapple with the challenge of producing robust and authoritatively objective truth in the midst of contending subjectivities associated with competing perspectives on bitterly divided and contested pasts.' ${ }^{11}$ The attempts to resolve this dilemma, Posel notes, have differed. South Africa's TRC, for example, was the first to install personal testimony at the heart of its project in an attempt to avoid the confrontational encounters of the legal trial. While South Africa's truth commission attempted to provide a supportive forum for the telling of traumatic personal stories, its model of transitional justice was, however, equally intent on verifying these stories as much as authenticating them. ${ }^{12}$ Hence, while there is no single formula for the composition of the truth commission, these quasi-juridical institutions all share the common problem of having to address the question: what constitutes truth?

In turning to Adrian Stimson's two projects on the residential school, we see that personal testimony in the context of the art event engages its audiences in differing understandings of this question of the truth. ${ }^{13}$ As Kyo McClear

7 Indian and Northern Affairs Canada 2006, Indian Residential Schools Settlement Agreement, Indian and Northern Affairs Canada, Ottawa,p. 15, <http://www.residentialschoolsettlement.ca/settlement.html>

8 Erasmus, George 2008, 'Preface', in Marlene Castellano-Brandt et al. (eds), From Truth to Reconciliation: Transforming the legacy of residential schools, Aboriginal Healing Foundation, Ottawa, p. xiii.

9 Rice, Bryan and Snyder, Anna 2008, 'Reconciliation in the context of a settler society: healing the legacy of colonialism in Canada', in Castellano-Brandt et al., From Truth to Reconciliation, p. 45.

10 Ibid.

11 Posel, Deborah 2008, 'History as confession: the case of the South African Truth and Reconciliation Commission', Public Culture, vol. 20, no. 1, Duke University Press, p. 120. Posel (p. 137) notes that in the South African TRC: 'Prior to each hearing the researchers within the relevant investigative bureaucracies were responsible for investigating the pending case so as to equip commissioners with information pertinent to a process of inquiry and cross-checking, alongside the activity of listening and validating the pain of the experiences.'

12 Ibid., p. 137.

13 As Rosanne Kennedy notes: 'One of the tensions in how testimony is received in different contexts concerns the contested issue of "truth", and differing understandings of what constitutes the truth.' (Kennedy, 
notes, '[a]rt cannot supplant courtroom proceedings and judicial procedure, nor should it'. ${ }^{14}$ What expressive culture does offer, however, is its ability 'to open up new sites of possibility by providing opportunities to see and hear what has become familiar, differently' and 'it may provoke memories that could not be generated elsewhere'. ${ }^{15}$ In Old Sun and Buffalo Boy's Confessional: Indulgence, Stimson's methods of testifying are not aligned symmetrically with those of the law or the quasi-juridical forms of testimony that occur in truth and reconciliation commissions. Indeed, quite the opposite. In the immersive, multi-sensory environments of Stimson's art events, we see a deliberate crossing of media and genres that makes it impossible for viewers to decide whether we are witnessing the fictional, the dreamt, the fantastical, the invented or effects of 'realness' in oblique self (and collective) portraiture. In stark contrast with the truth commission or the law, Stimson's visual testimony is concerned not with a central problem of 'truth' or 'accountability'. Rather, the force of his visual testimony lies in its ability to surprise and defamiliarise what it is we think we know. In Stimson's installations and performance events, the viewer encounters another way of telling whose value does not lie in any juridical analysis (by that standard his work can appear quite demented) but in art's 'infinite power to keep undecideable'. ${ }^{16}$ In breaking with the visual language of 'realism', Stimson uses multiple viewpoints, broken narratives, an elastic sense of time and surprising juxtapositions in his art events to unsettle meaning and to trouble the mind. His visual strategies of counterpoint and montage shift the viewer's attention from any received notions of 'truth' in the dominant society to the process of 'truth telling' itself, asking whose 'truths' make it into the archive in the first place and under what conditions. In Old Sun and Buffalo Boy's Confessional: Indulgence, Stimson asks us to reflect on differing regimes of intelligibility and visibility, bringing into play the very question: what is truth?

\section{Buffalo Boy testifies: Adrian Stimson}

Adrian Stimson is a Saskatoon-based artist and a member of the Siksika Nation in Alberta. His installation and performance projects belong to a tradition of art making that is intent on developing Indigenous and place-centred visual testimony that puts the apartheid memory work of Canada's colonial-settler

Rosanne 2008, Uses and abuses of testimony, Panel presentation, University of Saskatchewan, Saskatoon, Saskatchewan, 27 October 2008.)

14 McClear, Kyo 1999, Beclouded Visions: Hiroshima-Nagasaki and the art of witness, Albany State University of New York Press, New York, p. 86.

15 Ibid. McClear's work is among the rapidly growing archive of critical literature on the testimonial arts, which also includes, among others, Bennet, Jill 2005, Empathic Vision: Affect, trauma, and contemporary art, Stanford University Press, Stanford, California.

16 Derrida, Jacques 2003, Geneses, Genealogies, Genres, \& Genius: The secrets of the archive, Columbia University Press, New York, p. 18. 
cultures into crisis. In the past four decades, as Mary Longman notes in her essay in this collection, contemporary Indigenous artists in Canada have worked with persistence, courage and the decolonising power of the imagination to create an extensive archive of visual testimony that has two primary purposes: first, to bear witness to Canada's colonial past and its stubborn multifaceted legacies in the present; and second, 'to rebuild and reclaim the Aboriginal narrative'. This Indigenous-centred tradition of art making is deliberately 'worldly' in the sense that it seeks to be in conversation with its audience about the concerns of Indigenous people living in Canada's colonial-settler society. ${ }^{17}$

In the past decade, Stimson's multimedia work has addressed two major rhetorical silences in colonial-settler discourse: the situation and experience of Aboriginal peoples in the settlement era of the Canadian West and the genocidal policies of the residential school. In addition, his work has focused on Indigenous and queer issues of social and cultural justice. With the assistance of Buffalo Boy - his outrageous and sensational performance persona-he has developed a double axis of witnessing that sets out to Indigenize and queer the terrain of the national imaginary. We encounter, in Buffalo Boy's persona, the instrumental energy and play of a visual deconstructor at work. The multigendered Buffalo Boy - neither human nor beast, neither boy nor girl-is a master of improvisation, always on the move. In one moment, he is a brooding shaman exterminator; in another, he is a campy cowboy wearing a bison G-string, buffalo corset, disco cowboy hat and black fishnets. ${ }^{18}$ Mixing satiric spectacle, camp aesthetics and anti-colonial critique, Buffalo Boy restages and re-signifies various colonial encounters (in the past and present) as high-camp theatre, in which everything is done in 'quotations' and nothing is what it seems to be.

Active as an Indigenous politician for eight years, Stimson notes that he finds the arts to be a gentler place in which 'to deal with issues of residential schools, racism and homophobia' ${ }^{19}$ Working at the site of a number of cultural crossroads, Stimson articulates multiple subject positions in his work: he is a historian/ ethnographer of colonial culture and an anti-colonial activist producing resilient performances of Indigenous-centred agency; he is a Survivor intent on making

17 In Canada, as Rice and Snyder ('Reconciliation in the context of a settler society', p. 45) point out, any societal reconciliation that emerges from the Indian Residential Schools Settlement Agreement must address three major structural issues unique to a settler society - namely, 'the legacy of colonialism that impacts the political, social and economic life of Aboriginal people; historical and contemporary myths prevalent in Canadian society that rationalize Canada's policies and practices towards Aboriginal people; and the impact of colonization/residential schools on Aboriginal identities and mental health that adds an additional layer of healing to the reconciliation process'.

18 Buffalo Boy as the campy cowboy is a character parody of Buffalo Bill (aka William Cody) and his touring Wild West shows, which in the late nineteenth century created 'living pictures' of frontier life, including such spectacles as 'The Indian Races', 'Custer's Last Stand' and 'The Buffalo Hunt' (see Bell, Lynne 2007, 'Buffalo Boy: camp, mourning and history in the work of Adrian Stimson', Canadian Art, vol. 24, no. 2 [Summer], pp. $44-8$ at p. 47).

19 Ibid. 
recovery narratives to 'exorcise the negative energies that [still] exist' and a critical educator who uses ritual play as a site of decolonising resistance and pedagogy; and he is an inhabitant of Indigenous and Western cultures.

\section{Decolonising visual testimony}

In Old Sun (Figures 1, 2 and 3) and Buffalo Boy's Confessional: Indulgence (Figures 4 and 5), Stimson testifies to the experience of the residential school and its continuing legacies as a 'primary witness', as Dominic LaCapra puts it, 'who has lived through events and remembers them in a certain manner' ${ }^{20}$ In his residential school projects, Stimson's restless testimony works with the elliptical, affective and interrogative possibilities of the visual language. As Chilean-born artist Alfredo Jaar notes, however, 'it is difficult' to create effective testimony in the visual arts. ${ }^{21}$ It is about finding a strategy to bear witness that is suited to the specificities of the particular situation and moment out of which the art event emerges. It is always about the attempt to bear witness and the struggle to find adequate strategies to represent particular experiences and understandings. It is not about creating a topography of mastery. As McClear notes, the significance of the testimonial arts lies not in the generic truths they reveal but in what they ask of us, the viewer. In Old Sun and Buffalo Boy's Confessional: Indulgence, Stimson seeks to engage audiences in acts of indirect or secondary witnessing using dialogic, performative and participatory modes of address to get people to think about how colonialism inflicts trauma. As viewers, we are asked to become midwives to memories still caught in the throes of becoming. Our viewing presence - our intentions, blindness and sight-becomes part of the witnessing activity'. ${ }^{22}$ This witnessing activity, of course, will vary depending on the frames different spectators bring to the work in order to make it testify.

As Roger Simon notes, to be 'touched' or moved by another's testimony is to feel 'a form of human connection, an empathic response to another's story, involving such feelings as sorrow, shock, elation, rage'. ${ }^{23}$ In his visual testimony, Stimson works with the affective and embodied impacts of installation and performance art to engage his viewers emotionally and critically. In discussing these forms of doing and making art, critics Gill Perry and Kristine Stiles stress

\footnotetext{
20 LaCapra, Dominick 1998, History and Memory After Auschwitz, Cornell University Press, Ithaca and London, p. 20.

21 Jaar, Alfredo 2002, 'It is difficult', in Okwui Enwezor et al. (eds), Experiments with Truth: Transitional justice and the processes of truth and reconciliation. Documenta 11, Platform 2, Hatje Cantz (Ostfildern-Ruit), New York, pp. 289-311 at p. 305.

22 McClear, Beclouded Visions, p. 20.

23 Simon, Roger I. 2005, The Touch of the Past: Remembrance, learning and ethics, Palgrave Macmillan, New York, p. 188.
} 
that they require the active embodied involvement of the viewer. ${ }^{24}$ In these media, viewers are asked to respond kinaesthetically, to move in and around the works, to explore tensions between shifting viewing positions and (frequently) to engage with a wide range of sensory experiences. When information is spread across the sensory spectrum in the fleeting moment of the art event, it not only ensures its survival in memory, it increases its affective and embodied impact. In discussing the performance-based cultures of Aboriginal jurisprudence, $\mathrm{Sa}^{\prime} \mathrm{ke}^{\prime} \mathrm{j}$ Henderson notes that in the moment of the performance, every sensory experience or media becomes 'a hook from which the thread of memory can hang' ${ }^{25}$ Thus, if people do not immediately remember hearing something, they might remember seeing or feeling it. In addition, if 'several different media are used to transmit exactly the same message, the power of that message as a whole is reinforced to the point where the audience may have so much sensory input that distraction or passivity, and hence forgetting becomes impossible' ${ }^{26}$

Stimson's use of visual counterpoint in Old Sun and Buffalo Boy's Confessional: Indulgence creates moments of provocative dissonance that rely on the viewer to complete the meaning of the work as an active participant. In assembling images, objects, texts and performances together in the gallery space, he creates an inventory of traces of Indigenous and settler-colonial histories, revealing their interconnecting and overlapping existence in the Canadian West. It is a praxis of visual counterpoint that echoes Edward Said's critical practice of 'contrapuntal ethics' - a practice of reading the world and cultural texts, which involves a way of thinking 'comparatively, expansively and non-coercively' ${ }^{27}$ Stimson's art events presume a viewer to whom the responsibility of remembering can be passed. As McClear states: 'Testimonial art survives when it is taken on, when it enters dialogue - not when it is passively accepted. Because its messages are inherently unfinished, it is disruptive and demanding. ${ }^{28}$ If viewers are willing to share in the responsibility of meaning making in Stimson's art events, we become participatory witnesses, engaging in moments of testimonial exchange. As Roger Simon explains, a testimonial exchange is a transitive moment that carries information from one time and space to another. ${ }^{29}$ This transitive character of testimony means that its arrival in the gallery demands, as Simon puts it, 'doubled moments of attentiveness-one informational the other reflexive', in which viewers are challenged to learn about previously unheard

\footnotetext{
24 Perry, Gill 2004, 'Dream houses: installations and the home', in Gill Perry and Paul Wood (eds), Themes in Contemporary Art, Yale University Press in association with The Open University, New Haven and London, pp. 231-77; Stiles, Kristine 2004, 'I/Eye/Occulus: performance, installation, video', in Perry and Wood, Themes in Contemporary Art, pp. 183-231.

25 Henderson, First Nations Jurisprudence and Aboriginal Rights, p. 173.

26 Ibid.

27 Curthoys, Ned and Ganguly, Debjani 2007, Edward Said: The legacy of a public intellectual, Melbourne University Press, Victoria, Australia, p. 13.

28 McClear, Beclouded Visions, p. 188.

29 Simon, The Touch of the Past, p. 98.
} 
or unseen histories, facts and stories and, at the same time, to engage in a critical self-reflexive practice of remembrance that makes us think about what it is we think we know and how we know it. ${ }^{30}$ In Stimson's art events, we encounter an aesthetics of participation in which we are addressed individually yet feel part of a larger group that is beckoned to reconsider and remake 'what constitutes the character of public life' ${ }^{31}$

\section{Old Sun}

Walking into the spectral half-dark of Stimson's exhibit Old Sun in the Truck Gallery in Calgary, Alberta, the visitor encounters three installations: Old Sun (2005), Sick and Tired (2004) and Inhumation (2008). This installation trilogy is lit by internal points of light that illuminate the dim gallery. The sound of a shovel beating on the ground is as regular as a heartbeat or breathing.

The title, Old Sun, links Stimson's exhibit in downtown Calgary with Old Sun School, an Anglican residential school founded in 1890 on Stimson's home reserve of the Siksika Nation, just an hour's drive south-east of Calgary. Many of Stimson's family members were forced to attend Old Sun School, where many children died of tuberculosis, mumps, cholera, smallpox, influenza, measles and malnutrition - all in the name of civilisation. In successive government reports, Old Sun School became infamous for its high mortality rates; its buildings were condemned as unsanitary and its overcrowded dormitories were described as providing ideal incubators for the spread of disease. ${ }^{32}$ As Stimson notes in his essay in this collection, Old Sun School was named after 'Old Sun' or Natusapi, a chief of the Blackfoot and Stimson's distant relative:

I find it ironic that Old Sun School was named after this respected leader who did not want to sign Treaty 7, preferring war to what, at the time, was seen as the end of our way of life. Old Sun School did ensure the end of a way of life for his descendants, including my family. ${ }^{33}$

The focus of Stimson's exhibit is on the child's experience of the residential school and its processes of dehumanisation. Moving back and forth between the three installations that make up the exhibit brings together an accumulation of

\footnotetext{
30 Ibid., p. 100.

31 Ibid., p. 187.

32 For instance, Dr P. H. Bryce's The Story of a National Crime (1922) informed Canadians in graphic detail of what was being done in their name. As Milloy and Churchill point out, however, the deaths and conditions in these schools pricked no national conscience. Instead, the fates of First Nations people - and children - were not discussed in polite circles of 'Good Canadians'. Indeed, there was a withdrawal of empathy from these targeted groups (Churchill, Ward 2004, Kill the Indian, Save the Child: The genocidal impact of American Indian residential schools, City Lights Books, San Francisco, p. 44; Milloy, A National Crime, pp. 99-102).

33 Stimson, Adrian 2009, 'Used and abused', Humanities Research, vol. 3.
} 
images: a steel-ribbed sweat lodge lined with scraps of buffalo hide; a classroom light casting shadows that mimic the 'double-cross' of the Union Jack; a sleeping figure lying on an infirmary bed wrapped in buffalo fur; the phantom shadow of a flayed buffalo hide; a tall sketchy structure resembling a traditional burial platform of the Siksika Nation and a wooden coffin; a small fur sarcophagus suspended in front of a projection of flickering black-and-white images of Old Sun School; and an inverted Anglican church banner reading 'All One in Christ Jesus'. In the upside-down world of this installation event, we see the clash and juxtaposition of heterogeneous materials (such as fur and steel) and images (such as the sweat lodge and the Union Jack) testifying not only to the violent imposition of the colonial educational system on the Indigenous child, but to the continuing coexistence of Indigenous religious ceremonies alongside the compulsory Christianity of the residential school system, despite the colonial government's attempts to suppress Aboriginal traditions, rituals and social and political organisations that it perceived as obstacles to Christianity and civilisation. ${ }^{34}$

Stimson's three installations start from and continually return to an archive of physical traces or found objects: small fragments of material culture salvaged from renovations at Old Sun School, including windows, classroom lights, an infirmary bed and an instructor's album of 1950s black-and-white photographs of children at Old Sun School. Stimson notes:

These fragments bear witness to the trauma of these schools. They also invoke my relationship to the history of the residential school. I went to residential school until grade four as a day student. From a very early age I was aware of what was going on. I have a lot of vivid memories of things that occurred and I draw on them when I work with these fragments. The works are about forgiveness, forgiving yourself, recognizing that your mind has been programmed and foregrounding a way to release this. This is how I release it - through my art practice. ${ }^{35}$

Throughout Stimson's installation event, the figure of the child and the figure of the buffalo are palpable presences. In bringing these differing visual elements and signifying systems into juxtaposition, Stimson allusively yet insistently draws connections between two colonial crimes that are normally kept apart in the national imaginary: the cultural genocide inflicted on Indigenous children in the residential school system and the buffalo genocide and its devastating impact on the lifestyles of the Indigenous peoples of the Plains. In the Settlement Agreement, the figure of the child and the residential school system is seen to be powerfully symbolic of the flawed relations between Aboriginal and non-

34 Milloy, A National Crime, p. 21.

35 Bell, 'Buffalo Boy'. 
Aboriginal peoples in Canada. The realisation that children were harmed and children continue to be harmed now has the power to move Canadian society at large, although this was not always the case. ${ }^{36}$

In the third installation, entitled Inhumation, viewers encounter a small bisonfur sarcophagus hanging from a tall structure resembling a traditional burial platform of the Siksika Nation. A residential school light sits on the platform, shining a cone of light upwards onto a small wooden coffin. The back wall of the installation is animated with a video loop of flickering black-and-white images of Old Sun School, including aerial views of the school's graveyard with row upon row of small white crosses; intense close-ups of the building's monotonous brick walls; rapid movement through tall prairie grasses mimicking the gaze of a runaway child; and images of Buffalo Boy as the campy cowboy wearing angel wings and dancing in an act of coup in front of the huge cross dominating the skyline of Old Sun School. We see in this spectre of Buffalo Boy the figure of a haunting that involves a calling to account for Canada's apartheid culture of colonial education and its continuing legacies. This haunting is about a critical praxis of remembrance that involves, as Derrida puts it, learning to live with ghosts. ${ }^{37}$ It is a haunting that involves a return to the 'now' of the present and the urgent need to decolonise the policies and practices of Canada's contemporary educational institutions, as outlined in the Report of the Royal Commission on Aboriginal Peoples in 1996. ${ }^{38}$

Stimson's exhibit Old Sun is a site-specific event that makes the familiar space of the Truck Gallery seem unfamiliar. The Truck Gallery is housed in Calgary's Grain Exchange Building - a tall, handsome building that was built in the early 1900 s as a major landmark in the early settler society of Alberta. Few nonAboriginal people (then or now) know that the Grain Exchange Building and the city of Calgary are built on traditional Blackfoot territory. As many critics have noted, the spatial boundaries of a society's built culture reveal the 'others' it fears. The map indicating the location of residential schools in the Canadian West is thick with black dots yet the existence of these schools is rarely mentioned in settler histories of the West. In Old Sun, Stimson makes visible the public secret, or blind spot, in the structure of Canada's colonial-settler society and its centennial discourses of modernity, progress and development; the residential school is a public secret that is both remembered and forgotten in the same moment. ${ }^{39}$ Refusing this settler culture of denial, Stimson's exhibit Old

36 Castellano-Brandt et al., From Truth to Reconciliation, p. 404.

37 Derrida, Jacques 1994, Specters of Marx: The state of the debt, the work of mourning and the new international, Routledge, New York and London, p. 13.

38 Royal Commission on Aboriginal Peoples 1996, Report of the Royal Commission on Aboriginal Peoples. Volume 1: Looking forward, looking back, Minister of Supply and Services Canada, Ottawa, Ontario.

39 The residential school remains 'a significant part of Canadian history that is still unknown to most Canadians' (Indian Residential Schools Settlement Agreement, p. 15). 
Sun assembles a compelling theatre of visual testimony that testifies to Canada's apartheid histories of education. In this exhibit, the material fragment salvaged from the residential school is at once a marker of history invested with personal and communal significance and a visual interruption that counters the amnesia of Canadian public memory about its colonial history and the 'national crime' ${ }^{40}$ of the residential school.

Old Sun engages in the exhausting work of remembrance and mourning yet it also tells a story of survival, resistance and resilience. In his practice as an artist, Stimson repeatedly returns to the figure of the buffalo as a metaphor for spirituality, creativity and rebirth. In this exhibit, the figure of the buffalo is at once witness, mourner and survivor. As Stimson tells it:

I use the bison as a symbol representing the destruction of the Aboriginal way of life. But it also represents survival and cultural regeneration. The bison is central to Blackfoot being. The bison as icon and food source, as well as the whole history of its disappearance, is very much a part of my contemporary life. ${ }^{41}$

Old Sun is a memorial for the children subjected to the assimilative and genocidal culture of the residential schools; the missing children who still lie in unmarked graves in the corners of residential school graveyards; and the children yet to be born whose future will be impacted by the intergenerational legacies of residential school trauma. In conjuring up the absent presence of the residential school system, Old Sun creates a personal space for viewers directly affected by this colonial institution and a larger space of cultural memory for the nonAboriginal Canadian public.

\section{Buffalo Boy's Confessional: Indulgence}

In 2007, Stimson had a solo show entitled Buffalo Boy's Confessional: Indulgence at the Red Shift Gallery, a contemporary Aboriginal art gallery in Saskatoon, Saskatchewan. As the title signifies, this exhibit involves a parodic restaging of the Catholic technologies of the confessional and the indulgence in a performance project in which Stimson expresses - in visual and dramatic form - his strong feelings about the culpability of Western religions in Canada's colonial order as well as his doubts about the testimonial structures of the government-funded reconciliation project of the Indian Residential School Settlement Agreement.

The centrepiece of Buffalo Boy's Confessional: Indulgence is a double-chambered outhouse standing in the middle of the gallery. Close inspection reveals a marked

40 Milloy, A National Crime.

41 Bell, 'Buffalo Boy', p. 48. 
contrast in the decor of the two chambers of this weathered biffy: one is all stark simplicity with a small stone angel sitting on the 'throne', the other is as opulent as a baroque church with rich fabrics, buffalo hides, faceted mirrors, religious bric-a-brac and a rotating mirrored disco ball hanging over a 'throne' fit for a king. On opening night, Stimson transforms this double-stalled outhouse into a Christian confessional in a performance starring Buffalo Boy in the role of priest, pastor or commissioner, whose act of listening is crucial to the Christian practice of confession, forgiveness and absolution. In the billing for the performance, Stimson states:

Buffalo Boy's Confessional: Indulgence is an installation and performance that seeks to re-signify or in this case exorcise the Colonial Condition [in] which Religion was complicit...Buffalo Boy has always found it funny that confessing your sins can absolve, in the eyes of God, individuals and their unacceptable acts. And more so when history shows that the wealthy were more likely to be absolved as opposed to the poor, setting up a hierarchy of salvation...The outhouse, more commonly known as the 'shitter' is a place of release. The act of using the toilet is in many ways similar to confessing: the act of getting rid of the bad. In parodying the confessional and the indulgence, Buffalo Boy creates a space where questioning ideas of spirituality can happen... The recent Indian Residential school settlement process reminds him of the confessional process, yet in an odd reversal, through the common and independent review process, survivors relate their residential school experiences, a confession of sorts, in return a cash settlement is given, thus absolving the government and the church of their sins. Survivors are both confessor and absolver, as if it were that easy...For Buffalo Boy, Confessional Indulgence seeks to expose the shit, explore the outhouses of religion. It seeks to cleanse our need to seek and ask for absolution.

At the start of the performance, Buffalo Boy enters the gallery, resplendent in buffalo robes, holding his orb and sceptre - signifiers of high office. He delivers a ritual prayer intoned in Latin before locking himself into the cubicle filled with quasi-religious iconography. After filling in a petition for an indulgence, audience members enter the cubicle with the stone angel and stuff their petitions through a small glory hole fringed with dark buffalo fur. Sitting on his throne, Buffalo Boy reads each petition into a microphone and then pushes a signed indulgence and a shot of sacral vodka back through the glory hole. In this scatological and irreverent performance, Stimson opens up an interactive public space for personal revelation, confessional testimony and serious play that takes on a life of its own. In filling out the 'regrets' section of Buffalo Boy's petition for an indulgence, viewers are given a chance to publicly confess their regrets for leaving things undone, for not loving with their whole heart and for 
not loving their neighbours as themselves. This live event is simultaneously a form of play and a form of social critique that opens up a space of reflection in which to question the role of the Roman Catholic Church and other religions in the conception, design and management of the residential school system, asking: how did the residential school system happen? How were Christianity and responsibility perverted? Why did it happen ${ }^{42}$

In this live event, Buffalo Boy's sumptuous robes, imperial insignia and magnificent throne deliberately invoke the age of imperial religion in which the Catholic Church used the figure of God and three fifteenth-century papal bulls (edicts) to sanction and promote imperialism, European colonisation and the colonial project of subjugating and converting all non-Christian Indigenous populations. Decolonising memory work is, however, forward looking, engaging with history in order to deal effectively with its legacies in issues of social justice in the present. In this performance, Stimson addresses the racist and paternalistic attitudes of the Catholic Church in the past and the present. For instance, while Stimson was assembling his ideas for Buffalo Boy's Confessional: Indulgence, Pope Benedict XVI, in a startling replay of imperial religion, noted on a trip to Latin America in June 2007 that Catholicism had 'purified' Indigenous peoples and that the contemporary resurgence of Indigenous religions was a step backwards. ${ }^{43}$ In Buffalo Boy's Confessional: Indulgence, Stimson also draws attention to the Catholic Church's persistent homophobia. ${ }^{44}$ Invoking the power of the trinity of St Bison Bison, Buffalo Boy and the Glorious Hole in the written text of his indulgences, Stimson refuses the Catholic Church's current prohibitions against active queer lifestyles. He also challenges assumptions that two-spiritedness is excluded from Indigenous culture. Instead, he installs a particular Indigenous and queer-centred imaginative space at the very centre of this live testimonial project and its understandings of history, sexuality and identity.

In this live event, Stimson deactivates the sacred space of the confessional by linking it with 'the shitter' and the profane act of defecation. As philosopher Giorgio Agamben notes, '[t]o profane means not simply to abolish and erase separations' between the sacred and the profane, 'but to learn to put them to a new use, to play with them' ${ }^{45}$ In this live event, Stimson puts the confessional to new uses, filling it with a campy carnival that testifies to the heterogeneity of difference and diversity in everyday life. In petitioning for an indulgence,

\footnotetext{
42 Milloy, A National Crime, p. xix.

43 Love, David 2007, 'Pope Benedict argues Catholic Church "purified" indigenous peoples', The Black Commentator, 18 June 2007, <http://www.alternet.org/story/54407/1-9.,1>

44 On 22 December 2008, Pope Benedict, in an end-of-year speech to senior Vatican staff, stated that 'saving humanity from homosexual and transsexual behaviour [is] as important as protecting the environment' (BBC News Online).

45 Agamben, Giorgio 2007, Profanations, Zone Books, New York, p. 87.
} 
viewers confess to a multiplicity of 'regrets' that test the limits of the Roman Catholic Church's hierarchical distinctions between good over evil, sacred over profane, purity over impurity, heterosexual over homosexual and serious over frivolous - to name a few key oppositions. In appropriating and re-signifying the confessional and the indulgence, Stimson unsettles the Catholic Church's constructed system of values, revealing all that it still excludes and casts outside the temple.

Another way of reading the serious play of Buffalo Boy's Confessional: Indulgence is in terms of a serious critique directed at the testimonial structures of the CEP, IAP and the TRC in the Settlement Agreement. It has been argued by a number of cultural critics that the emphasis on Survivor testimony in national reconciliation projects such as truth and reconciliation commissions works to install the Christian confessional as the most powerful discursive paradigm through which these projects operate. Indeed, the emphasis on reconciliation and not retribution in Canada's Settlement Agreement foregrounds not only a Christian discourse of forgiveness but a therapeutic discourse of healing, bringing together the symbolic spaces of the couch and the confessional, as opposed to the more combative antagonistic space of the courtroom. ${ }^{46}$ In conversation, Stimson notes:

I see an absolute correlation between the common and independent review processes and the Roman Catholic Church's Indulgence system. Only the CEP and IAP twist this process. Instead of the perpetrators having to confess their sins it is Aboriginal peoples who have to confess their pain. We confess our pain and the government assumes the role of the church and gives us an Indulgence, or not, depending on the criteria they have developed. The burden of proof is on us. Shouldn't they be seeking absolution from us? It makes me angry. The performance is a way to exorcise all of this. ${ }^{47}$

The Christian confessional is a space in which 'truths' are supposedly given freely, yet as Foucault points out, power is in operation in the confessional just as much as in the inquisition torture chamber with its 'forced' truths. ${ }^{48}$ Thinking about the operation of power in the confessional raises a host of questions about the use of personal testimony in the CEP, IAP and the TRC, including: will survivor testimony in these contexts lead to healing and catharsis or will it lead to more trauma, reopening and reinfecting old wounds? Will people feel pressured to revisit buried trauma in order to receive compensation? If a Survivor's testimony is deemed invalid according to the criteria of the Settlement Agreement will

\footnotetext{
46 Moon, Claire 2008, Narrating Political Reconciliation: South Africa's Truth and Reconciliation Commission, Lexington Books, Lanham, pp. 91-114.

47 Unpublished conversation with the artist, June 2008.

48 Moon, Narrating Political Reconciliation, p. 93.
} 
these Survivors feel excluded from the apology and re-victimised as secondclass witnesses? Does the focus on individual testimony in the various processes of the Settlement Agreement deflect attention from the collective struggle for Aboriginal post-secondary education in Canada ${ }^{49}$

\section{The testimonial arts in a colonial-settler society}

Stimson's visual testimony opens up a conversation about the right of Indigenous peoples to have rights in colonial-settler societies. As many critics have noted, the dominant focus of government-funded national reconciliation projects such as truth and reconciliation commissions has been the exploration of humanrights violations. ${ }^{50}$ Few critics, however, have noted that until 2007, the paradigm of international human rights did not specifically include the rights of the world's Indigenous peoples. This situation was rectified in 2007, when member states of the United Nations voted overwhelmingly to endorse the United Nations Declaration on the Rights of Indigenous Peoples. As Henderson notes in his book Indigenous Diplomacy and the Rights of Peoples, this declaration sets a new standard in international human rights by extending human rights and fundamental freedoms to Indigenous people. As Henderson points out, it is significant that the declaration on the rights of Indigenous peoples was opposed in the United Nations by the settler states of Australia, New Zealand, the United States and Canada. ${ }^{51} \mathrm{He}$ further notes that the Indigenous diplomacy movement that worked for 30 years at the United Nations to get this declaration passed did not receive 'any substantial help from these powerful colonial settler states', yet it did receive the support of 'the postcolonial nations in the General Assembly and their 21 st-century sensibilities' ${ }^{52}$

49 See the 'Recommendations of the Royal Commission on Aboriginal Peoples Regarding Post-Secondary Education' in Stonechild, Blair 2006, The New Buffalo: The struggle for Aboriginal post-secondary education in Canada, Manitoba Press, Winnipeg, Manitoba, pp. 144-6.

50 Kennedy, Uses and abuses of testimony.

51 As Henderson notes, the Aboriginal peoples of Canada have ratified the declaration under their existing Aboriginal and treaty rights. Also, on 8 April 2008, the House of Commons passed a motion in favour of implementing the declaration: 'This resolution expresses the will of the House and of Canadians, and should override the executive decision of the [Conservative] government to reject the Declaration' (Henderson, James [Sa'ke'j] Youngblood 2008, Indigenous Diplomacy and the Rights of Indigenous Peoples: Achieving UN recognition, Purich Publishing Ltd, Saskatoon, Saskatchewan, p. 95). He continues, however, that this resolution has not resolved the need for continuing political action on implementing the declaration (p. 97). 52 Ibid., p. 12. Henderson argues that if the colonial-settler state of Canada is to become a fully postcolonial nation with twenty-first-century sensibilities, continual political action is required to ensure that the standards contained in the declaration are implemented (p. 95). In the declaration, the State is required to 'respect the inherent rights and treaty rights of Indigenous peoples, [to] recognize their self-determination and their institutions, and [to] displace colonial legislation with the rights affirmed in the Declaration'. The declaration further requires 'every state to represent all of the people within its borders without discrimination, [to] establish new collaborative and co-operative relations, and [to] reaffirm that the assimilation or exploitation of any people constitutes a violation of their human rights' (ibid., p. 96). 
Stimson's visual testimony on the residential school system in Old Sun and Buffalo Boy's Confessional: Indulgence achieves historical and contextual agency within the wider network of meaning provided by the Report of The Royal Commission on Aboriginal Peoples (1996), the court-ordered Settlement Agreement (2006), the TRC (2008), the Day of Apology in the House of Commons (2008) and the United Nations Declaration on the Rights of Indigenous Peoples (2007). The convergence of these (and other) events in the past few years has created a 'discursive threshold', ${ }^{53}$ which enables new speaking positions and new public frameworks of visibility and intelligibility within which Survivor testimony across a range of genres and media can be witnessed by the wider Canadian public. These testimonial events have created 'communities of memory'54 in the public sphere that are educating all Canadians not only about the urgent need for practices of critical remembrance that do not erase or camouflage the violent colonial history of Canada's apartheid culture of education, but in the urgent need to decolonise the current educational system. ${ }^{55}$ In bringing people together to engage in a conversation about the residential school system, Stimson's art events offer opportunities for social bonding - and the formation of communities of memory and affiliation in the public sphere based on new cultural understandings and connections. Stimson's visual storytelling for social and cultural justice within the space of the art gallery (and beyond) is making a distinctive and important contribution to the mobilisation of public opinion and the power it has to demand radical change.

\footnotetext{
53 Whitlock, Gillian 2000, Soft Weapons: Autobiography in transit, University of Chicago Press, Chicago.

54 Simon, The Touch of the Past, pp. 61-3.

55 Battiste, Marie, Bell, Lynne and Findlay, Len M. 2002, 'Decolonizing education in Canadian universities: an interdisciplinary, international, indigenous research project', Canadian Journal of Native Education, vol. 26, no. 2, pp. 82-96; Battiste, Marie, Bell, Lynne and Findlay, L. M. 2002, 'An interview with Linda Tuhiwai Te Rina Smith', Canadian Journal of Native Education, vol. 26, no. 2, pp. 169-87.
} 